\title{
ENANTIOSELECTIVE SYNTHESIS OF LOBELINE VIA NONENZYMATIC DESYMMETRIZATION
}

Vladimir B. Birman, ${ }^{*}$ Hui Jiang and Ximin Li

A contribution from the Department of Chemistry, Washington University, Campus Box 1134, One Brookings Drive, Saint Louis, Missouri 63130

SUPPORTING INFORMATION: Experimental procedures (9 pages), ${ }^{1} \mathrm{H}$ NMR and ${ }^{13} \mathrm{C}$ NMR spectra (6 pages).

\section{Experimental Part.}

1. General. All reagents were obtained commercially and used as received unless otherwise specified. Catalyst $\mathbf{7}^{12}$ and substrate $\mathbf{1 0}^{22}$ were prepared as previously described.

Solvents used for chromatography were ACS or HPLC grade. Reactions were monitored by thin layer chromatography (TLC) using EM Science 60F silica gel plates. Flash column chromatography was performed over ICN Ecochrom silica gel $(32-63 \mu \mathrm{m})$. Deuterated chloroform used for catalytic activity measurements was obtained from Aldrich and was freshly distilled from anhydrous potassium carbonate. N,N-diisopropylethylamine was distilled from potassium hydroxide pellets. ${ }^{1} \mathrm{H}$ NMR and ${ }^{13} \mathrm{C}$ NMR spectra were recorded on a Unity $300 \mathrm{MHz}$ Varian spectrometer. The chemical shifts are reported as $\delta$ values (ppm) relative to TMS using residual $\mathrm{CHCl}_{3}$ peak $(7.26 \mathrm{ppm})$ as the reference. High-Resolution mass spectral analyses were performed at Washington University MS Center on a Kratos MS-50TA spectrometer using electron impact (EI) or fast atom bombardment (FAB) methods. Infrared spectra were recorded on a Perkin-Elmer Spectrum Bx FTIR spectrophotometer using potassium bromide plates. Melting points were measured on a Thomas-Hoover capillary melting point apparatus. HPLC separation of enantiomers was achieved on CHIRALPAK AD-H and CHIRALCEL OD-H analytical columns (4.6x250 mm, Chiral Technologies, Inc.) using a Shimadzu HPLC system.

\section{Synthesis of $( \pm)$-sedamine and $( \pm)$-allo-sedamine}

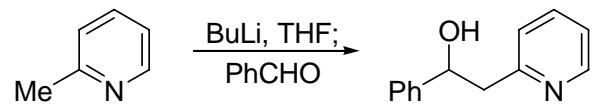

(士)-11

(a) ( \pm )-2-Pyridyl-1-phenylethanol (11) ${ }^{15} \quad$ A solution of n-butyllithium in hexanes $(21.0 \mathrm{~mL}$, $2.5 \mathrm{M}, 52.5 \mathrm{mmol}$ ) was added over a period of 5 minutes to a solution of freshly distilled $\alpha$-picoline $(4.66 \mathrm{~g}, 4.95 \mathrm{~mL}, 50.0 \mathrm{mmol})$ in $25 \mathrm{~mL}$ of THF stirred at $-78{ }^{\circ} \mathrm{C}$. The resulting orange suspension was allowed to warm to $0{ }^{\circ} \mathrm{C}$ until all the solid dissolved and cooled to -20 ${ }^{\circ} \mathrm{C}$. A solution of freshly distilled benzaldehyde $(5.28 \mathrm{~g}, 5.05 \mathrm{~mL}, 49.7 \mathrm{mmol})$ in $10 \mathrm{~mL}$ of THF was added dropwise. The reaction mixture was allowed to warm to $0{ }^{\circ} \mathrm{C}$ and quenched with water. Enough dichloromethane was added to dissolve the precipitated product. The organic 
phase was washed 3 times with brine and dried over $\mathrm{MgSO}_{4}$. Evaporation of the solvent produced light-yellow crystalline mass, which was suspended in $50 \mathrm{~mL}$ of $\mathrm{Et}_{2} \mathrm{O}$, filtered off and rinsed with $\mathrm{Et}_{2} \mathrm{O}(3 \times 10 \mathrm{~mL})$ to give $6.42 \mathrm{~g}$ of the product $\left(65 \%\right.$, mp. $109.5-110{ }^{\circ} \mathrm{C}$, lit. ${ }^{23} 110-111$ $\left.{ }^{\circ} \mathrm{C}\right)$. Concentration of the filtrate gave an additional $0.64 \mathrm{~g}$ of the product $(6.5 \%$, mp. 108.5-109 $\left.{ }^{\circ} \mathrm{C}\right)$. The two crops were combined and used in the next step without further purification.

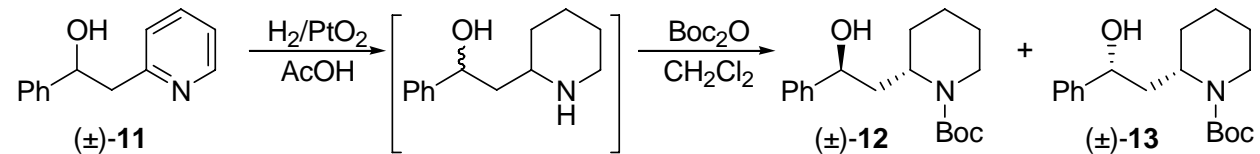

(b) ( \pm )-N-Boc-norsedamine (12) and $( \pm)$-N-Boc-norallosedamine (13). ${ }^{16-18} \quad$ A mixture of 2pyridyl-1-phenylethanol $( \pm)-\mathbf{1 1}(1.00 \mathrm{~g}, 5.03 \mathrm{mmol}), 50 \mathrm{mg}$ of $\mathrm{PtO}_{2}$, and $14 \mathrm{~mL}$ of glacial acetic acid was hydrogenated under atmospheric pressure until the disappearance of the starting material by TLC (5-7 h). The reaction mixture was filtered through a cotton plug, basified carefully with $50 \% \mathrm{NaOH}$, diluted with water and extracted with $\mathrm{CH}_{2} \mathrm{Cl}_{2} 3$ times. The extract was dried over $\mathrm{Na}_{2} \mathrm{SO}_{4}$ and rotary evaporated. The evaporation residue was redissolved in 10 $\mathrm{mL}$ of $\mathrm{CH}_{2} \mathrm{Cl}_{2}$ and treated with $\mathrm{Boc}_{2} \mathrm{O}(1.20 \mathrm{~g}, 5.50 \mathrm{mmol})$ in $10 \mathrm{~mL}$ of $\mathrm{CH}_{2} \mathrm{Cl}_{2}$ at rt. The mixture was left overnight and rotary evaporated. Flash chromatography $(6 \%$ acetone in hexanes) afforded (in the order of elution) $362 \mathrm{mg}$ (24\% yield) of almost pure crystalline 13 and $772 \mathrm{mg}$ (50\% yield) of pure $\mathbf{1 2}$ as a viscous oil. Recrystallization of $\mathbf{1 3}$ from hexanes was used to obtain an analytically pure sample.

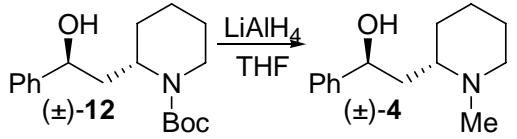

(c) ( \pm )-Sedamine (4) $)^{17,18}$ A solution of $12(308 \mathrm{mg}, 1.00 \mathrm{mmol})$ in $15 \mathrm{~mL}$ THF was added dropwise to a suspension of $\mathrm{LiAH}_{4}(224 \mathrm{mg}, 5.90 \mathrm{mmol})$ in $15 \mathrm{~mL}$ of THF under the atmosphere of nitrogen. The reaction mixture was stirred at $\mathrm{rt}$ for $0.5 \mathrm{~h}$ and then refluxed for $5.5 \mathrm{~h}$. The mixture was cooled to $0{ }^{\circ} \mathrm{C}$, quenched by addition of several drops of water followed by $20 \%$ aqueous $\mathrm{NaOH}$ to $\mathrm{pH}$ 14. The mixture was extracted with $\mathrm{CH}_{2} \mathrm{Cl}_{2} 3$ times and dried over $\mathrm{Na}_{2} \mathrm{SO}_{4}$. After evaporation of the solvent, $217 \mathrm{mg}$ (98\% yield) of 4 was obtained. The product was pure by ${ }^{1} \mathrm{H}$ NMR except for $\leq 2 \%$ of 5 and was used for kinetic resolution experiments without further purification.

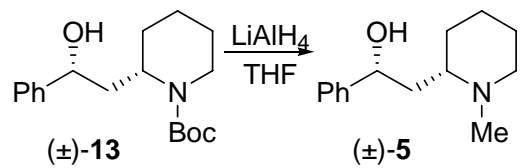

(d) ( \pm )-Allosedamine (5) ${ }^{17,18}$ The above procedure was followed to obtain $\mathbf{5}$ from $\mathbf{1 3}$ in $99 \%$ yield. The product was pure by ${ }^{1} \mathrm{H}$ NMR except for $\leq 2 \%$ of 4 and was used for kinetic resolution experiments without further purification. 


\section{Acylation of model substrates}

(a) Background reaction at room temperature. A solution of a substrate $(0.125 \mathrm{mmol})$ and $\mathrm{N}$,N-diisopropylethylamine (12 mg, $16 \mu \mathrm{L}, 0.094 \mathrm{mmol}, 0.75$ equiv) in $0.50 \mathrm{~mL}$ of $\mathrm{CDCl}_{3}$ was stirred with $50 \mathrm{mg}$ of anhydrous $\mathrm{Na}_{2} \mathrm{SO}_{4}$ in a 1 dram vial. Propionic anhydride $(12 \mathrm{mg}, 12 \mu \mathrm{L}$, 0.094 mmol, 0.75 equiv) was added. The solution was transferred into an NMR tube and monitored periodically by ${ }^{1} \mathrm{H}$ NMR.

(b) Background reaction of $( \pm)-\mathbf{1 0}$ at $\mathbf{0}$ and $-\mathbf{2 0}{ }^{\circ} \mathbf{C}$. A stock solution of amino alcohol 10 (237 $\mathrm{mg}, 1.32 \mathrm{mmol}$ ) and $\mathrm{N}, \mathrm{N}$-diisopropylethylamine $\left(129 \mathrm{mg}, 174 \mu \mathrm{L}, 1.00 \mathrm{mmol}\right.$ ) in $\mathrm{CDCl}_{3}$ (total volume $5.3 \mathrm{~mL}$ ) was distributed in $0.5 \mathrm{~mL}$ portions into ten 1 dram vials each containing $50 \mathrm{mg}$ of anhydrous $\mathrm{Na}_{2} \mathrm{SO}_{4}$. Five of the vials were cooled in an ice bath; the remaining five were cooled in a freezer to $-20 \pm 3{ }^{\circ} \mathrm{C}$. After 15 minutes, propionic anhydride ( $12 \mu \mathrm{L}, 0.75$ equiv) was added to each vial. After 3, 6, 10, 11, and $12 \mathrm{~h}$, the contents of one of the five vials kept in the ice bath was treated with diethylamine (ca. $15 \mu \mathrm{L})$ and analyzed by ${ }^{1} \mathrm{H}$ NMR indicating 22, 33, 43, 48, and 50\% conversion, respectively. The vials kept in the freezer were analyzed in an analogous fashion, indicating 28, 38, and 49\% conversion after 14, 24 and $39 \mathrm{~h}$, respectively.

(c) Kinetic resolution experiments. Kinetic resolutions were carried out in the presence of (R)-BTM (2.5 mg, $0.010 \mathrm{mmol}, 8 \mathrm{~mol} \%)$ in a manner analogous to the uncatalyzed acylation experiments described above. Each experiment was performed in duplicate. The reactions were monitored by ${ }^{1} \mathrm{H}$ NMR and quenched by addition of $0.5 \mathrm{~mL}$ of methanol when the conversion reached ca. 50\%. The quenched reaction mixtures were concentrated and directly subjected to column chromatography. The previously described procedure for HPLC analysis of the product and the recovered starting material was followed. ${ }^{12}$ HPLC data are given in Table $3 \mathrm{~S}$.

Table 1S.

\begin{tabular}{|c|c|c|c|c|}
\hline entry & substrate & temp & time & $\%$ convn \\
\hline 1 & $\mathbf{9}$ & $\mathrm{rt}$ & $48 \mathrm{~h}$ & $<1$ \\
\hline 2 & $\mathbf{1 0}$ & $\mathrm{rt}$ & $175 \mathrm{~min}$ & 50 \\
\hline 3 & $\mathbf{1 0}$ & $0{ }^{\circ} \mathrm{C}$ & $12 \mathrm{~h}$ & 50 \\
\hline 4 & $\mathbf{1 0}$ & $-20{ }^{\circ} \mathrm{C}$ & $40 \mathrm{~h}$ & 49 \\
\hline 5 & $\mathbf{4}$ & $\mathrm{rt}$ & $44 \mathrm{~min}$ & 50 \\
\hline 6 & $\mathbf{5}$ & $\mathrm{rt}$ & $220 \mathrm{~min}$ & 50 \\
\hline
\end{tabular}


Table 2S.

\begin{tabular}{|c|c|c|c|c|c|c|c|}
\hline entry & substrate & temp & time & $\%$ convn & $e_{P}$ & $e_{S M}$ & $\mathrm{~S}$ \\
\hline 1 & \multirow{2}{*}{9} & \multirow{2}{*}{$0{ }^{\circ} \mathrm{C}$} & \multirow{2}{*}{$8 \mathrm{~h}$} & 51 & 92.5 & 94.7 & 93.5 \\
\hline 2 & & & & 51 & 92.4 & 94.8 & 92.9 \\
\hline 3 & \multirow{2}{*}{10} & \multirow{2}{*}{$0{ }^{\circ} \mathrm{C}$} & \multirow{2}{*}{$5.5 \mathrm{~h}$} & 42 & 67.7 & 48.3 & 8.28 \\
\hline 4 & & & & 45 & 65.3 & 54.4 & 8.10 \\
\hline 5 & \multirow{2}{*}{4} & \multirow{2}{*}{$0{ }^{\circ} \mathrm{C}$} & \multirow{2}{*}{$50 \mathrm{~min}$} & 52 & 81.6 & 88.6 & 28.9 \\
\hline 6 & & & & 51 & 82.7 & 86.0 & 29.0 \\
\hline 7 & \multirow{2}{*}{4} & \multirow{2}{*}{$-20{ }^{\circ} \mathrm{C}$} & \multirow{2}{*}{$3.5 \mathrm{~h}$} & 54 & 83.6 & 97.2 & 47.1 \\
\hline 8 & & & & 54 & 83.0 & 98.7 & 53.0 \\
\hline 9 & \multirow{2}{*}{5} & \multirow{2}{*}{$0{ }^{\circ} \mathrm{C}$} & \multirow{2}{*}{$7 \mathrm{~h}$} & 50 & 50.1 & 49.2 & 4.8 \\
\hline 10 & & & & 48 & 48.7 & 44.7 & 4.4 \\
\hline
\end{tabular}

Table 3S.

\begin{tabular}{|c|c|c|c|}
\hline \multirow{2}{*}{ substrate } & HPLC conditions & \multicolumn{2}{|c|}{$\begin{array}{c}\text { Retention time } \\
\text { (min) }\end{array}$} \\
\cline { 3 - 4 } & $\mathbf{R})$ & $(\mathrm{S})$ \\
\hline $\mathbf{1 0}$ & $\begin{array}{c}5 \% \mathrm{i}-\mathrm{PrOH} / 0.1 \% \mathrm{HNEt}_{2} / \text { hexanes } \\
1 \mathrm{~mL} / \mathrm{min}, \mathrm{OD}-\mathrm{H}\end{array}$ & 8.5 & 12.6 \\
\hline $\mathbf{4}$ & $\begin{array}{c}4 \% \mathrm{i}-\mathrm{PrOH} / 0.1 \% \mathrm{HNEt} / \mathrm{hexanes} \\
1 \mathrm{~mL} / \mathrm{min}, \mathrm{OD}-\mathrm{H}\end{array}$ & 11.9 & 15.8 \\
\hline $\mathbf{5}$ & $\begin{array}{c}1 \% \mathrm{i}-\mathrm{PrOH} / 0.2 \% \mathrm{HNEt}_{2} / \text { hexanes } \\
1 \mathrm{~mL} / \mathrm{min}, \mathrm{OD}_{-} \mathrm{H}\end{array}$ & 13.8 & 18.0 \\
\hline
\end{tabular}

\section{Synthesis of lobelanidine (3). ${ }^{7}$}

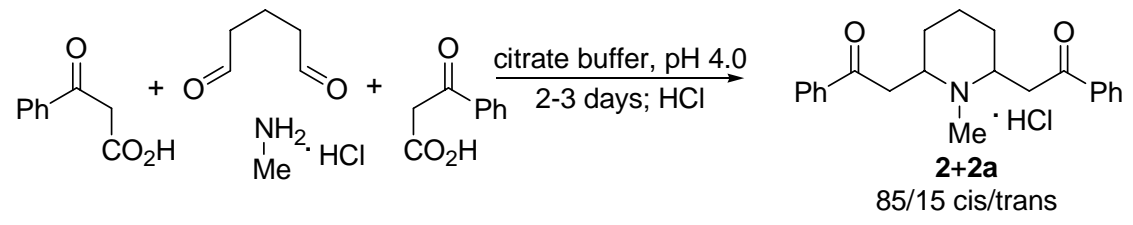

(a) Lobelanine hydrochloride (2). A mixture of benzoylacetic acid (2.29 g, $13.9 \mathrm{mmol})$, $\mathrm{MeNH}_{2} \cdot \mathrm{HCl}(0.458 \mathrm{~g}, 6.8 \mathrm{mmol}), 25 \%$ aqueous solution of glutaraldehyde $(2.1 \mathrm{~mL}, 5.2 \mathrm{mmol})$ and $200 \mathrm{~mL}$ of citrate buffer $(0.05 \mathrm{M}, \mathrm{pH} 4.0)$ was stirred for 2 days at room temperature, then washed with hexane twice, acidified with $4 \mathrm{M} \mathrm{HCl}$ to $\mathrm{pH}<1$, and stirred to form white precipitate. The precipitate was filtered off, rinsed with a minimal amount of water and dried. The crude product $(0.878 \mathrm{~g}, 45 \%$ yield $)$ was taken to the next step directly without further purification. ${ }^{1} \mathrm{H}$ NMR spectrum of this material indicated the presence of two compounds, 
assumed to be the cis- and the trans-isomers of lobelanine, in 85:15 ratio (by integration of the singlets at $\delta 2.78$ and $\delta 2.89$ corresponding to the N-Me groups of the two isomers).

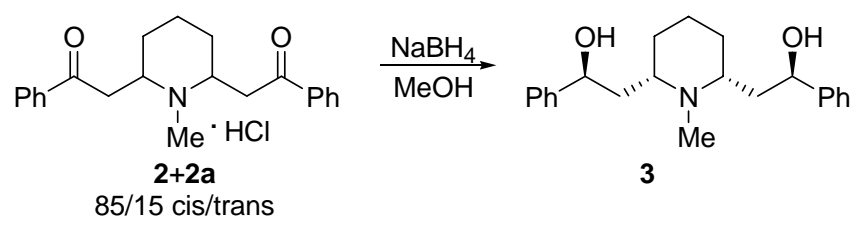

(b) Lobelanidine (3). Crude lobelanine hydrochloride (0.803 g, $2.16 \mathrm{mmol})$ was dissolved in 8 $\mathrm{mL}$ of $\mathrm{MeOH}$. Sodium borohydride $(0.49 \mathrm{~g}, 13 \mathrm{mmol})$ was added slowly, and the resulting mixture was stirred at room temperature overnight. Excess borohydride was quenched by dropwise addition of $6 \mathrm{~N} \mathrm{HCl}$ to $\mathrm{pH}<2$. After a few minutes of stirring, white granular crystals precipitated. The stirring was continued for $2 \mathrm{~h}$, the crystals was filtered off, treated with saturated aqueous $\mathrm{NaHCO}_{3}$, extracted with $\mathrm{CHCl}_{3}$, and concentrated to produce $0.474 \mathrm{~g}$ of white crystalline product $\left(65 \%\right.$ yield). ${ }^{1} \mathrm{H}$ NMR data were identical to those previously reported. ${ }^{24}$

\section{Desymmetrization of lobelanidine.}

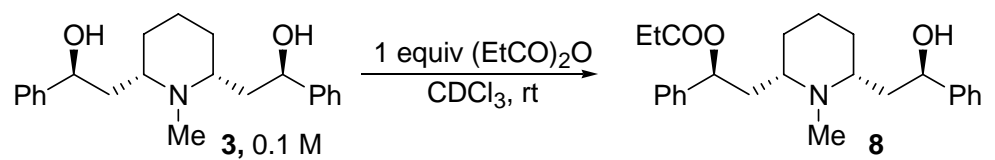

(a) Optimization study (see Table 2 of the manuscript).

Set of Conditions A. To a solution of lobelanidine (17 mg, $0.050 \mathrm{mmol})$, N,Ndiisopropylethylamine $(8.8 \mu \mathrm{L}, 0.050 \mathrm{mmol})$ and, optionally, (S)-BTM [1.25 mg, $0.0050 \mathrm{mmol}$ $(10 \mathrm{~mol} \%)$; or $2.5 \mathrm{mg}, 0.010 \mathrm{mmol}(20 \mathrm{~mol} \%)]$ in $0.5 \mathrm{~mL}$ of freshly distilled $\mathrm{CDCl}_{3}$ stirred with $50 \mathrm{mg}$ of anhydrous $\mathrm{Na}_{2} \mathrm{SO}_{4}$ was added propionic anhydride $(6.4 \mu \mathrm{L}, 0.050 \mathrm{mmol})$. After 60 minutes, the reaction mixture was quenched by addition of diethylamine ( $5 \mu \mathrm{L}, 0.05 \mathrm{mmol})$. The ratio of the unreacted starting material 3 to monoester 8 and diester 14 was estimated using ${ }^{1} \mathrm{H}$ NMR. Reaction mixtures containing BTM were separated by column chromatography $5 \%$ isopropanol in hexanes $\rightarrow 5 \%$ isopropanol $+1 \%$ triethylamine in hexanes). Isolated monoester 8 was analyzed by chiral stationary phase HPLC.

Set of Conditions B. The experiments were carried out analogously to those described above, except that N,N-diisopropylethylamine was omitted.

\section{(b) Preparative scale desymmetrization.}

Set of Conditions C: To a solution of lobelanidine (68 mg, $0.200 \mathrm{mmol})$ and (S)-BTM (10 $\mathrm{mg}, 0.040 \mathrm{mmol}$ ) in $2.0 \mathrm{~mL}$ of $\mathrm{CDCl}_{3}$ stirred at $\mathrm{rt}$ with $100 \mathrm{mg}$ of $\mathrm{Na}_{2} \mathrm{SO}_{4}$ was added propionic anhydride $(28 \mu \mathrm{L}, 0.220 \mathrm{mmol}, 1.1$ equiv.). The mixture was stirred for 2 days and separated by column chromatography ( $5 \%$ isopropanol in hexanes $\rightarrow 5 \%$ isopropanol $+1 \%$ triethylamine in hexanes) to yield (in the order of elution) $7 \mathrm{mg}$ of diester 14 (7.8\% yield), $5 \mathrm{mg}$ of BTM (50\% recovery) and $73 \mathrm{mg}$ of enantiomerically pure (S,R)-monoester $\mathbf{8}$ (92\% yield). 
Set of Conditions D: To a solution of lobelanidine $(170 \mathrm{mg}, 0.500 \mathrm{mmol})$, N,Ndiisopropylethylamine $(87 \mu \mathrm{L}, 0.50 \mathrm{mmol})$ and (R)-BTM $(25 \mathrm{mg}, 0.10 \mathrm{mmol})$ in $5.0 \mathrm{~mL}$ of $\mathrm{CDCl}_{3}$ stirred at $\mathrm{rt}$ with $100 \mathrm{mg}$ of $\mathrm{Na}_{2} \mathrm{SO}_{4}$ was added propionic anhydride $(64 \mu \mathrm{L}, 0.50 \mathrm{mmol}$, 1.0 equiv.). Chromatography yielded $175 \mathrm{mg}$ of enantiomerically pure (R,S)-monoester ent-8 (88\% yield) and $14 \mathrm{mg}$ of lobelanidine (8\% recovery).

\section{(c) Control studies}

Catalyzed vs. Uncatalyzed acylation of lobelanidine. The basic set of conditions A was used. Stock solution \#1 containing lobelanidine $(272 \mathrm{mg}, 0.801 \mathrm{mmol})$ and N,Ndiisopropylethylamine $(140 \mu \mathrm{L}, 0.801 \mathrm{mmol})$ in freshly distilled $\mathrm{CDCl}_{3}(8 \mathrm{~mL}$ total volume $)$ was distributed in $0.5 \mathrm{~mL}$ portions into 15 one-dram vials containing $50 \mathrm{mg}$ of anhydrous $\mathrm{Na}_{2} \mathrm{SO}_{4}$ each. Propionic anhydride $(6.4 \mu \mathrm{L}, 0.05 \mathrm{mmol}, 1$ equiv) was added into each vial, and timing was started. Reaction mixtures in individual vials were quenched by addition of diethylamine at different moments. The ratio of the unreacted starting material $\mathbf{3}$ to monoester $\mathbf{8}$ in each reaction was estimated using ${ }^{1} \mathrm{H}$ NMR. No appreciable diester 14 formation was detected $(\sim 1 \%$ at 60 min). The data obtained were plotted on the graph shown in Figure 1 ("Uncatalyzed"). In the same fashion, catalyzed acylation experiments were carried out using stock solutions \#2 and \#3, containing $10 \mathrm{~mol} \%$ of (S)-BTM (20 mg, $0.080 \mathrm{mmol})$ and $20 \mathrm{~mol} \%$ of (S)-BTM (40 mg, 0.160 $\mathrm{mmol})$, respectively, in addition to the aforementioned ingredients. The data obtained were plotted on the graph shown in Figure 1 ("10 mol \% (S)-BTM", "20 mol \% (S)-BTM").

Enantiomeric excess vs. Conversion. Reaction mixtures obtained from Solution \#3 (see above) and quenched at $1,3,8,30$ and 60 minutes were separated by column chromatography $(5 \%$ isopropanol in hexane $\rightarrow 5 \%$ isopropanol $+1 \%$ triethylamine in hexane). Isolated monoester 8 was analyzed by chiral stationary phase HPLC. The data obtained were plotted on the graph shown in Figure 2.

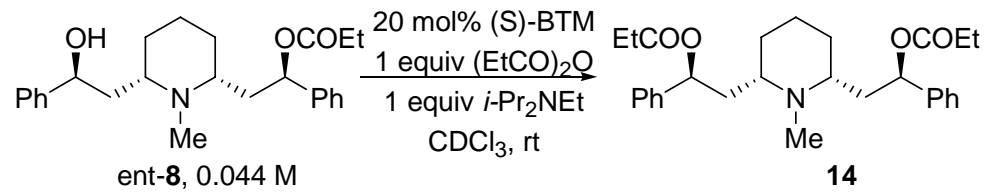

Catalyzed vs. Uncatalyzed acylation of (R,S)-lobelanidine monopropionate. Enantiopure (R,S)-monoester ent-8 was prepared as described above using (R)-BTM (see Set of Conditions D). Stock solution \#4 was prepared from ent-8 (52 mg, $0.13 \mathrm{mmol})$, (S)-BTM (6.7 mg, $20 \mathrm{~mol} \%$ ) and $i-\operatorname{Pr}_{2} \mathrm{NEt}\left(23 \mu \mathrm{L}, 1\right.$ equiv) in $3.0 \mathrm{~mL}$ of freshly distilled $\mathrm{CDCl}_{3}$. Stock solution \#5 was prepared from ent-8 (59 mg, $0.15 \mathrm{mmol})$, and $i$ - $\operatorname{Pr}_{2} \mathrm{NEt}(26 \mu \mathrm{L}, 1$ equiv) in $3.4 \mathrm{~mL}$ of freshly distilled $\mathrm{CDCl}_{3}$. Each of these solutions was distributed in $0.5 \mathrm{~mL}$ portions into 5 one-dram vials containing $50 \mathrm{mg}$ of anhydrous $\mathrm{Na}_{2} \mathrm{SO}_{4}$. Propionic anhydride $(2.8 \mu \mathrm{L}, 0.022 \mathrm{mmol}, 1$ equiv) was added into each vial, and timing was started. Individual vials were quenched by addition of diethylamine at different moments and the mixtures analyzed by ${ }^{1} \mathrm{H}$ NMR. After 5 min, 10\% conversion was reached in the catalyzed acylation; after $60 \mathrm{~min}, 38 \%$ conversion. In the absence of the catalyst, the conversion reached only $1-2 \%$ after $60 \mathrm{~min}$. 
Figure 1: BTM-catalyzed vs. uncatalyzed acylation of lobelanidine with $(\mathrm{EtCO})_{2} \mathrm{O}$

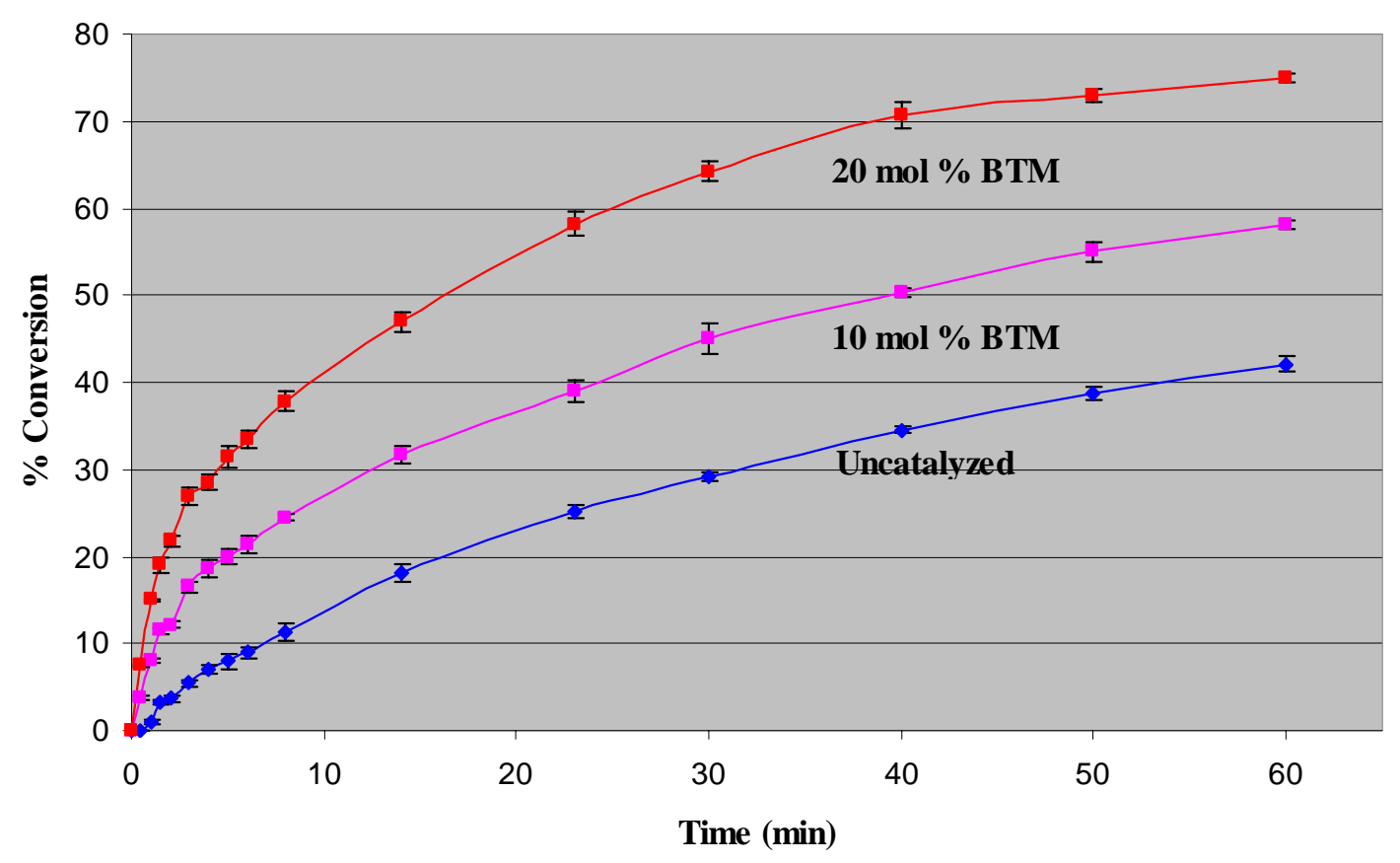

Figure 2: Ee vs. conversion

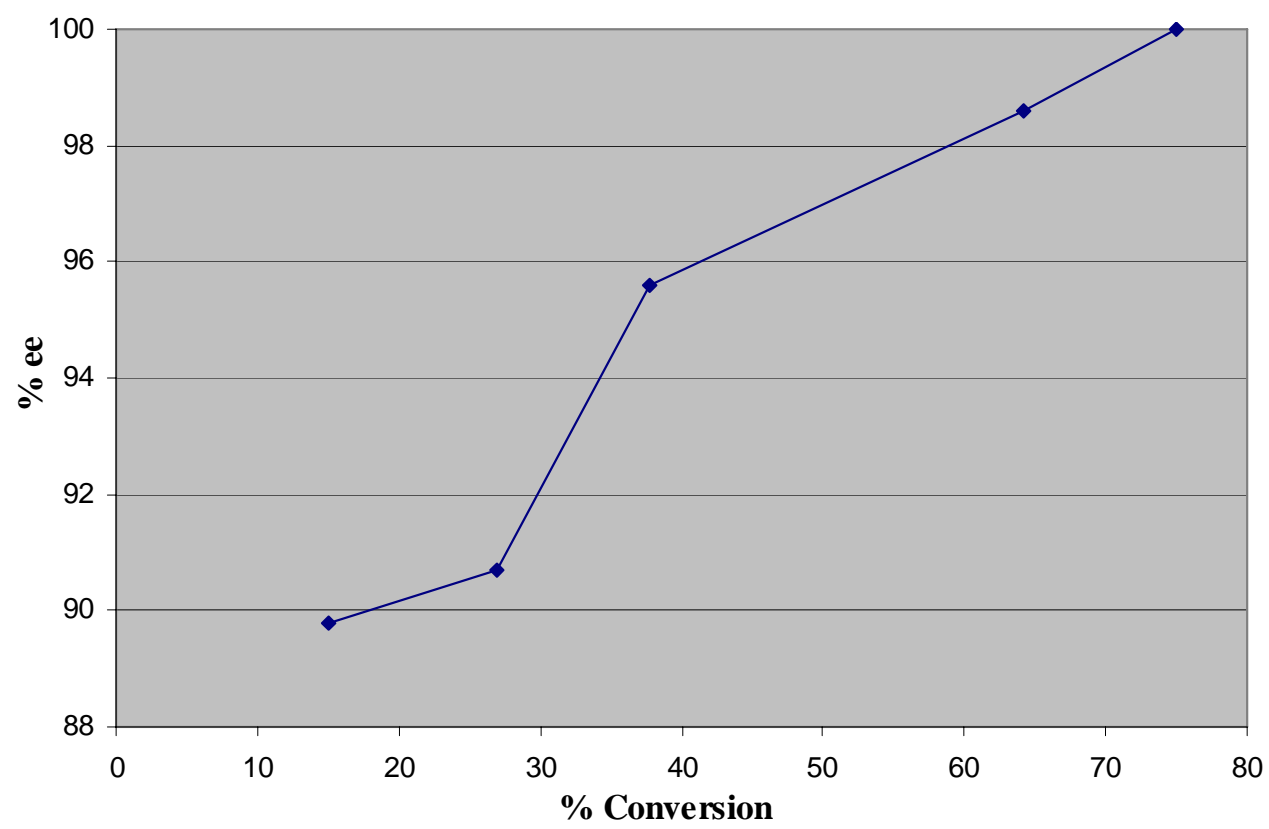




\section{(d) Characterization of new compounds}

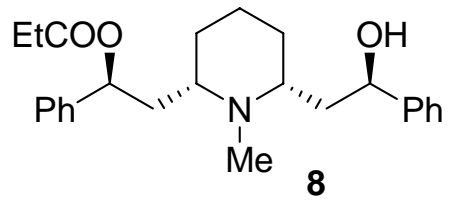

${ }^{1} \mathbf{H}$ NMR $\left(300 \mathrm{MHz}, \mathrm{CDCl}_{3}\right) \delta$ 7.46-7.22 (m; 10H), $5.80(\mathrm{t} ; \mathrm{J}=7.3$ $\mathrm{Hz} ; 1 \mathrm{H}), 5.00\left(\mathrm{dd} ; \mathrm{J}_{1}=10.8 \mathrm{~Hz}, \mathrm{~J}_{2}=2.6 \mathrm{~Hz} ; 1 \mathrm{H}\right), 3.08(\mathrm{t}, \mathrm{br} ; \mathrm{J}=$ $11.1 \mathrm{~Hz} ; 1 \mathrm{H}), 2.70(\mathrm{~m} ; 1 \mathrm{H}), 2.44-2.17(\mathrm{~m} ; 3 \mathrm{H}), 2.39(\mathrm{~s} ; 3 \mathrm{H}), 1.97$ $(\mathrm{m} ; 1 \mathrm{H}), 1.80-1.68(\mathrm{~m} ; 2 \mathrm{H}), 1.62-1.43(\mathrm{~m} ; 4 \mathrm{H}), 1.38-1.20(\mathrm{~m} ; 1 \mathrm{H})$, $1.14(\mathrm{t} ; \mathrm{J}=7.5 \mathrm{~Hz} ; 3 \mathrm{H}), 1.20-1.08(\mathrm{~m} ; 1 \mathrm{H}) ;{ }^{13} \mathrm{C}$ NMR $(75 \mathrm{MHz}$, $\left.\mathrm{CDCl}_{3}\right) \delta 173.7,145.0,140.1,128.5,128.1,128.0,126.9,126.8,125.4,75.8,73.6,64.4,59.0$, 40.5, 40.4, 27.7, 25.7, 24.8, 23.3, 22.8, 9.0; MS: HR-ESI calculated for $\mathrm{C}_{25} \mathrm{H}_{33} \mathrm{NO}_{3} \mathrm{H}\left(\mathrm{M}+\mathrm{H}^{+}\right)$ $\mathrm{m} / \mathrm{z}: 396.2539$, measured m/z: 396.2528; IR $\left(\mathrm{KBr}, \mathrm{cm}^{-1}\right)$ 1732; HPLC: $(8 \% \mathrm{i}-\mathrm{PrOH} / \mathrm{hexane}$, AD-H, 1mL/min) 10 min (R), $24 \min (\mathrm{S})$.

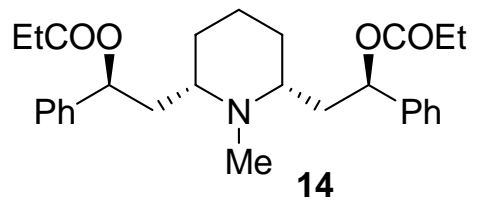

${ }^{1} \mathbf{H}$ NMR $\left(300 \mathrm{MHz}, \mathrm{CDCl}_{3}\right) \delta$ 7.40-7.26 (m; 10H), $5.89(\mathrm{t} ; \mathrm{J}=7.0$ $\mathrm{Hz} ; 2 \mathrm{H}), 2.43-2.20(\mathrm{~m} ; 8 \mathrm{H}), 2.28(\mathrm{~s} ; 3 \mathrm{H}), 1.73-1.64(\mathrm{~m} ; 3 \mathrm{H}), 1.52-$ $1.20(\mathrm{~m} ; 5 \mathrm{H}), 1.14(\mathrm{t} ; \mathrm{J}=7.5 \mathrm{~Hz} ; 6 \mathrm{H}) ;{ }^{13} \mathbf{C}$ NMR $\left(75 \mathrm{MHz}, \mathrm{CDCl}_{3}\right)$ $\delta 173.8,141.0,128.5,127.9,126.8,73.7,59.2,41.1,28.0,27.8$, 25.0, 24.4, 9.2; MS: HR-ESI calculated for $\mathrm{C}_{28} \mathrm{H}_{37} \mathrm{NO}_{4} \mathrm{H}\left(\mathrm{M}+\mathrm{H}^{+}\right)$ $\mathrm{m} / \mathrm{z}: 452.2801$, measured m/z: 452.2800; IR $\left(\mathrm{KBr}, \mathrm{cm}^{-1}\right) 1734$.

\section{Synthesis of $(-)$-Lobeline $(1)$ and $(+)$-Lobeline (ent-1).}
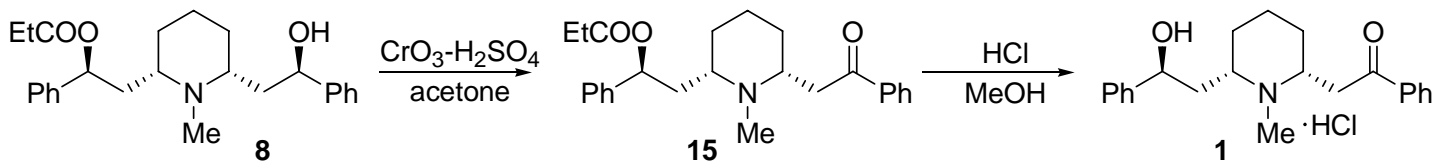

Monoester $8(160 \mathrm{mg}, 0.40 \mathrm{mmol})$ was dissolved in $5 \mathrm{~mL}$ of acetone, cooled to $0{ }^{\circ} \mathrm{C}$, and treated with Jones reagent ( $46 \mathrm{mg}$ of $\mathrm{CrO}_{3}, 40 \mu \mathrm{L}$ of conc. $\mathrm{H}_{2} \mathrm{SO}_{4}$, and $144 \mu \mathrm{L}$ of $\mathrm{H}_{2} \mathrm{O}$ ) added dropwise. After the addition was complete, the reaction mixture was stirred at room temperature for $1 \mathrm{~h}$ and diluted with chloroform. Saturated aqueous $\mathrm{NaHCO}_{3}$ was added gradually, taking care not to exceed $\mathrm{pH} 8$, until the organic phase became colorless. The organic phase was separated, washed with brine and concentrated to give the crude intermediate $\mathbf{1 5}$ as colorless oil, which was immediately dissolved in $16 \mathrm{~mL}$ of $\mathrm{MeOH}$ and $8 \mathrm{~mL}$ of $4 \mathrm{~N} \mathrm{HCl}$, and refluxed overnight. The solvent was removed under vacuum, producing slightly yellow oil, which was recrystallized from 2-propanol and hexanes to afford $88 \mathrm{mg}$ of the $1^{\text {st }}$ crop (58\% yield) and 20 $\mathrm{mg}$ of the $2^{\text {nd }}$ crop (13\% yield). NMR data were identical to those of a commercial sample of $(-)$ lobeline hydrochloride. Mp 178.0-178.5 ${ }^{\circ} \mathrm{C}$, (commercial sample: $\mathrm{mp} 179.5-180.0{ }^{\circ} \mathrm{C}$; 1 it: ${ }^{25} \mathrm{mp}$ $\left.181{ }^{\circ} \mathrm{C}\right)$. Optical rotation $[\alpha]_{20} \mathrm{D}=-58.6^{\circ}\left(\mathrm{c} 0.64, \mathrm{H}_{2} \mathrm{O}\right)\left(\right.$ lit.: ${ }^{26}[\alpha]_{20} \mathrm{D}=-57^{\circ}\left(\right.$ c $\left.2.0, \mathrm{H}_{2} \mathrm{O}\right)$ ). Enantiomeric $(+)$-lobeline hydrochloride was prepared analogously from ent-8, which, in turn, was obtained using (R)-BTM in the desymmetrization step (see Section 5b, Set of Conditions D). Mp 178.0 178.5 ${ }^{\circ} \mathrm{C},[\alpha]_{20} \mathrm{D}=+58.6^{\circ}\left(\mathrm{c} 0.36, \mathrm{H}_{2} \mathrm{O}\right)$.

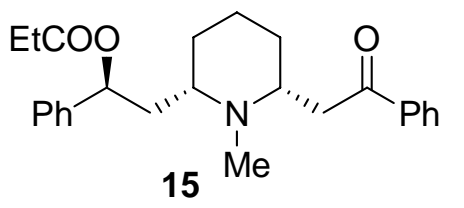

${ }^{1} \mathbf{H}$ NMR $\left(300 \mathrm{MHz}, \mathrm{CDCl}_{3}\right) \delta 8.00(\mathrm{~d} ; 2 \mathrm{H}), 7.60-7.22(\mathrm{~m} ; 8 \mathrm{H})$, $5.82(\mathrm{t} ; 1 \mathrm{H}), 3.23(\mathrm{dd} ; 1 \mathrm{H}), 3.17(\mathrm{~m} ; 1 \mathrm{H}), 2.92(\mathrm{~m} ; 1 \mathrm{H}), 2.40-2.20$ 
(m; 4H), $2.30(\mathrm{~s} ; 3 \mathrm{H}), 1.77-1.58(\mathrm{~m} ; 2 \mathrm{H}), 1.50-1.22(\mathrm{~m} ; 5 \mathrm{H}), 1.15(\mathrm{t} ; 3 \mathrm{H}) ;{ }^{13} \mathbf{C}$ NMR $(75 \mathrm{MHz}$, $\left.\mathrm{CDCl}_{3}\right) \delta 198.8,173.4,140.7,136.9,132.8,128.5,128.1,128.0,127.5,126.3,73.4,59.5,59.2$, $44.3,40.9,30.2,27.7,26.1,25.5,24.4,8.9$.

\section{ADDITIONAL REFERENCES}

${ }^{22}$ Perrine, D. M.; Sabanayagam, N. R.; Reynolds, K. J. J. Chem. Ed. 1998, 75, 1266.

${ }^{23}$ Betts, M. J.; Brown, B. R. J. Chem. Soc., C 1967, 1730.

${ }^{24}$ Crooks, P. A.; Dwoskin, L.P.; Miller, D. K.; Grinevich, V. P.; Norrholm, S. D.; Zheng, G. US Pat. 6703406 (2004).

${ }^{25}$ Steinegger, E.; Gruetter, H.; Pharm. Acta Helv. 1950, 25, 276.

${ }^{26}$ Glaser, R.; Hug, P.; Drouin, M.; Michael, A.; J. Chem. Soc., Perkin Trans. 2 1992, 7, 1071 


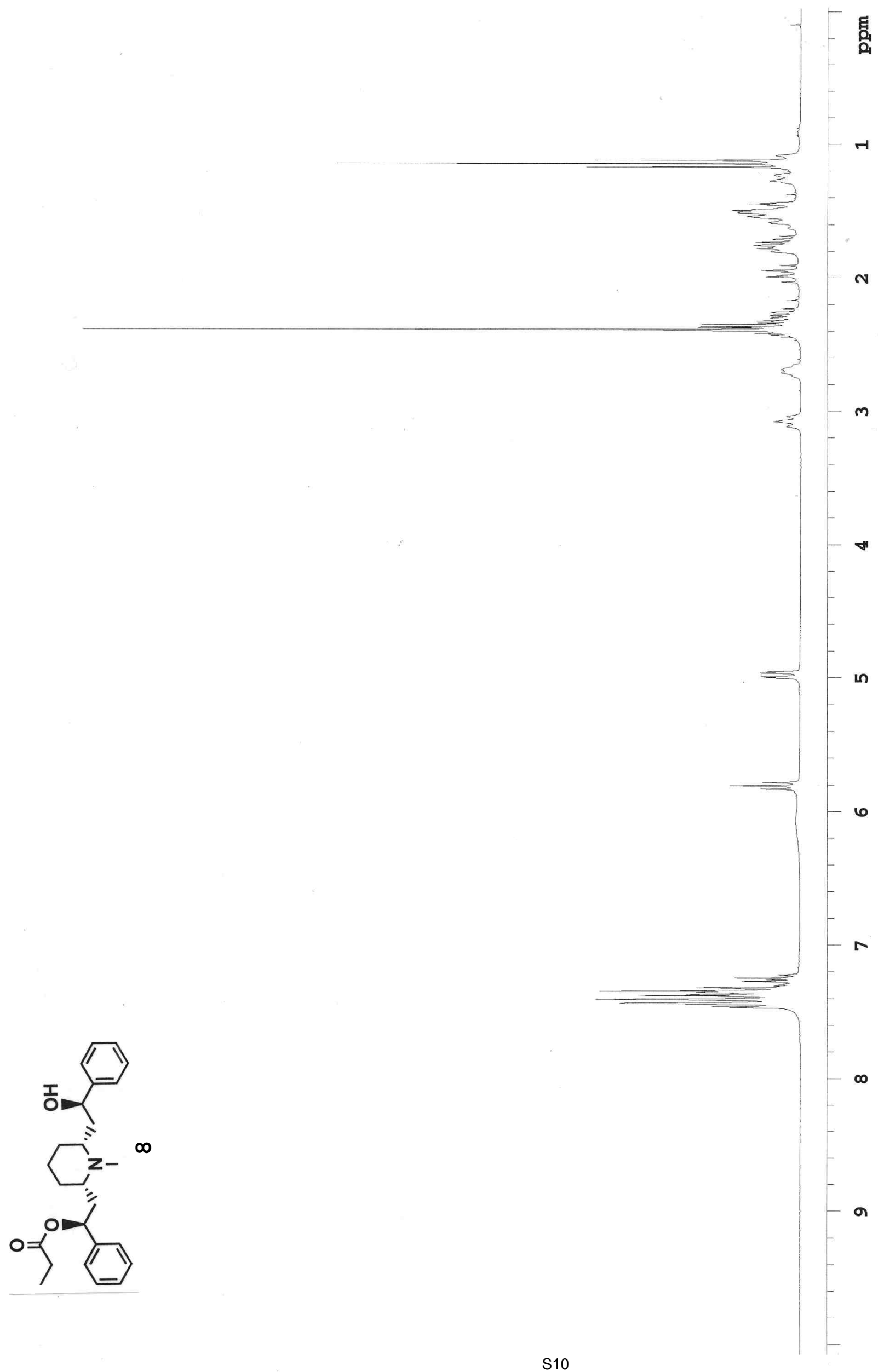




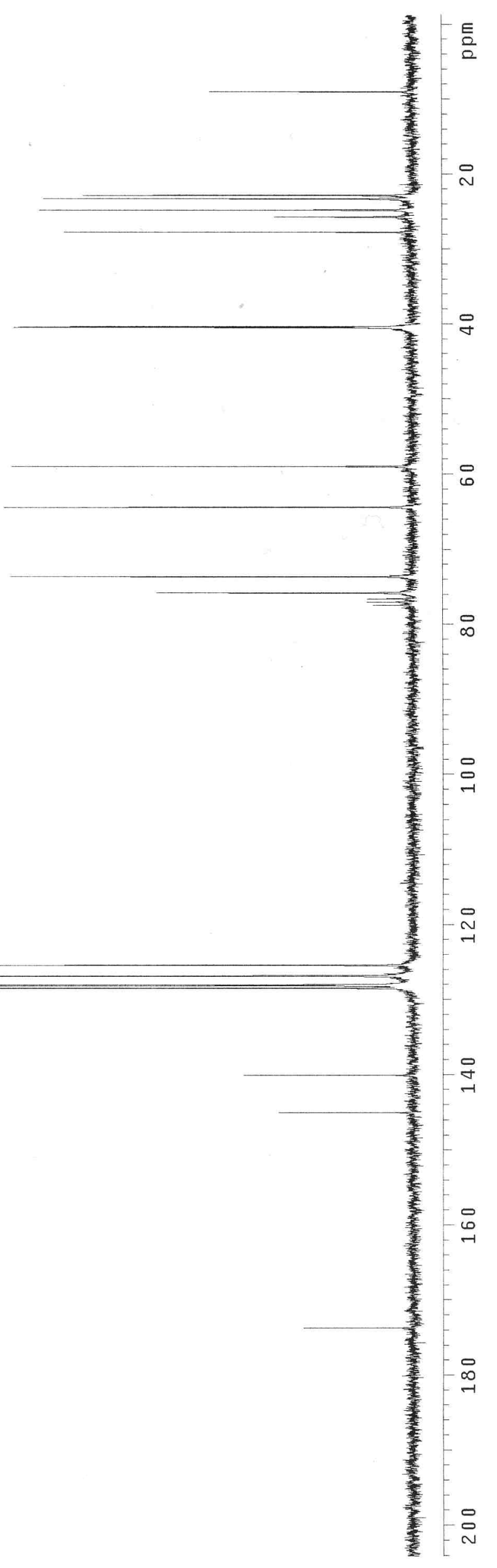




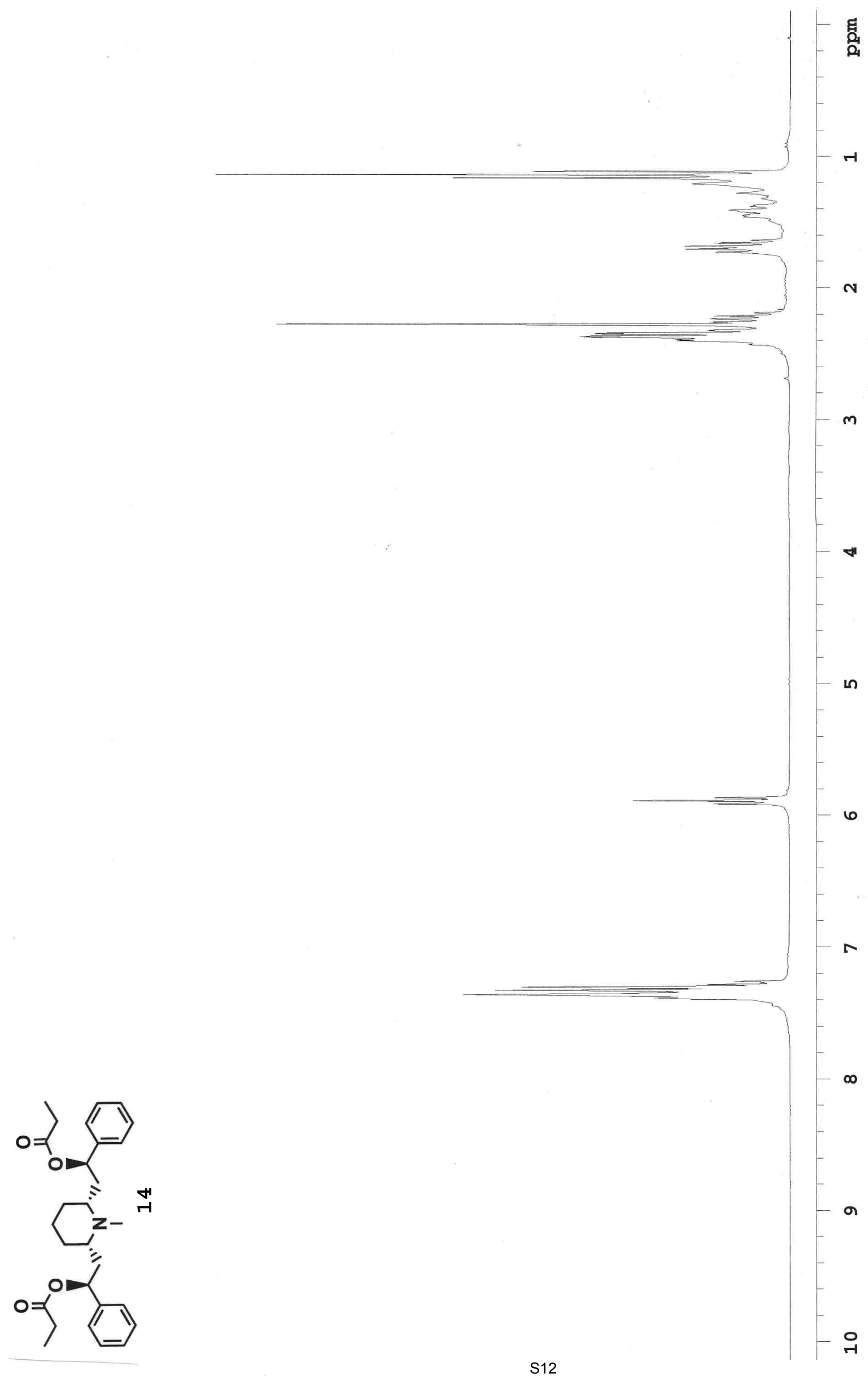




$$
y
$$




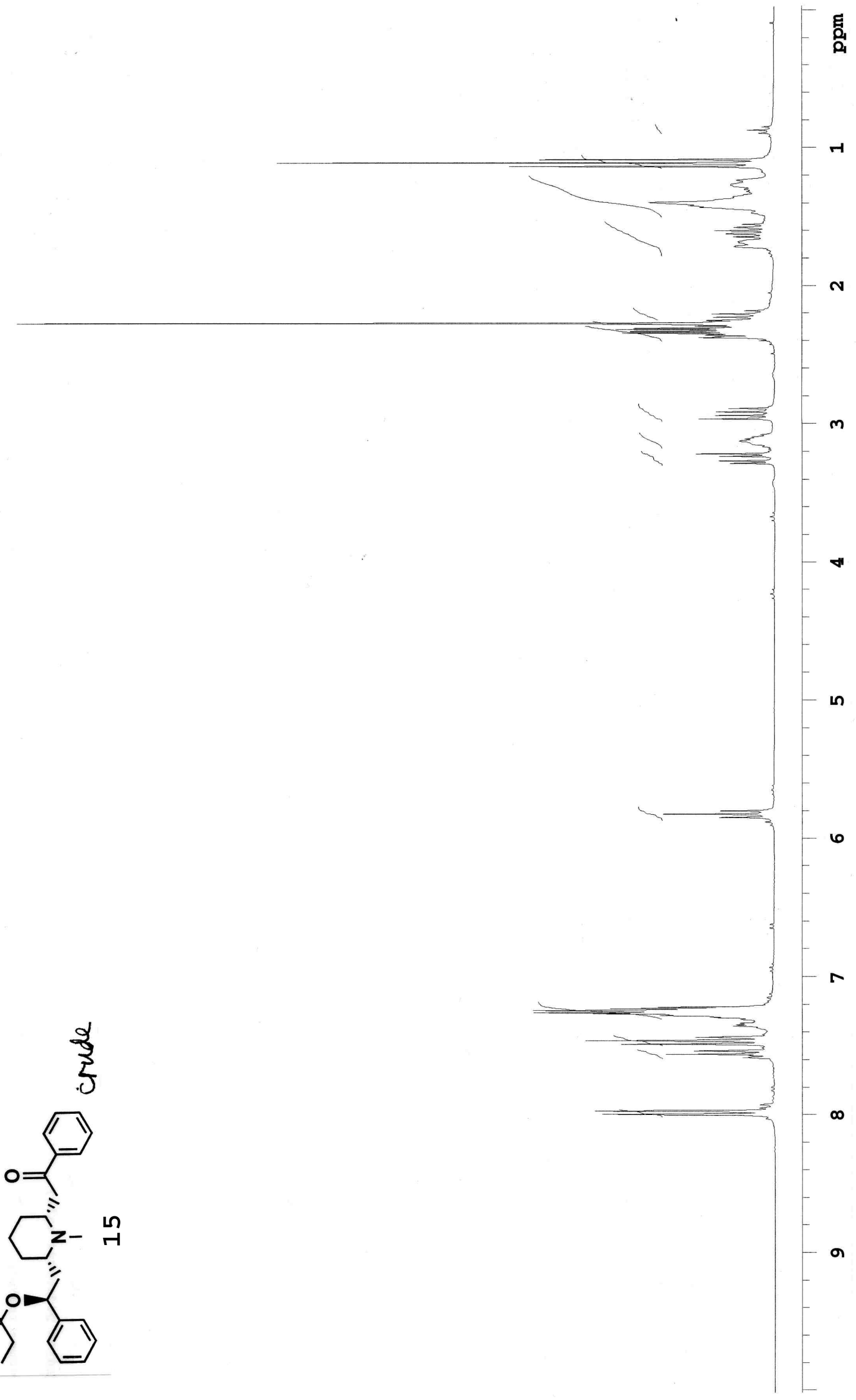




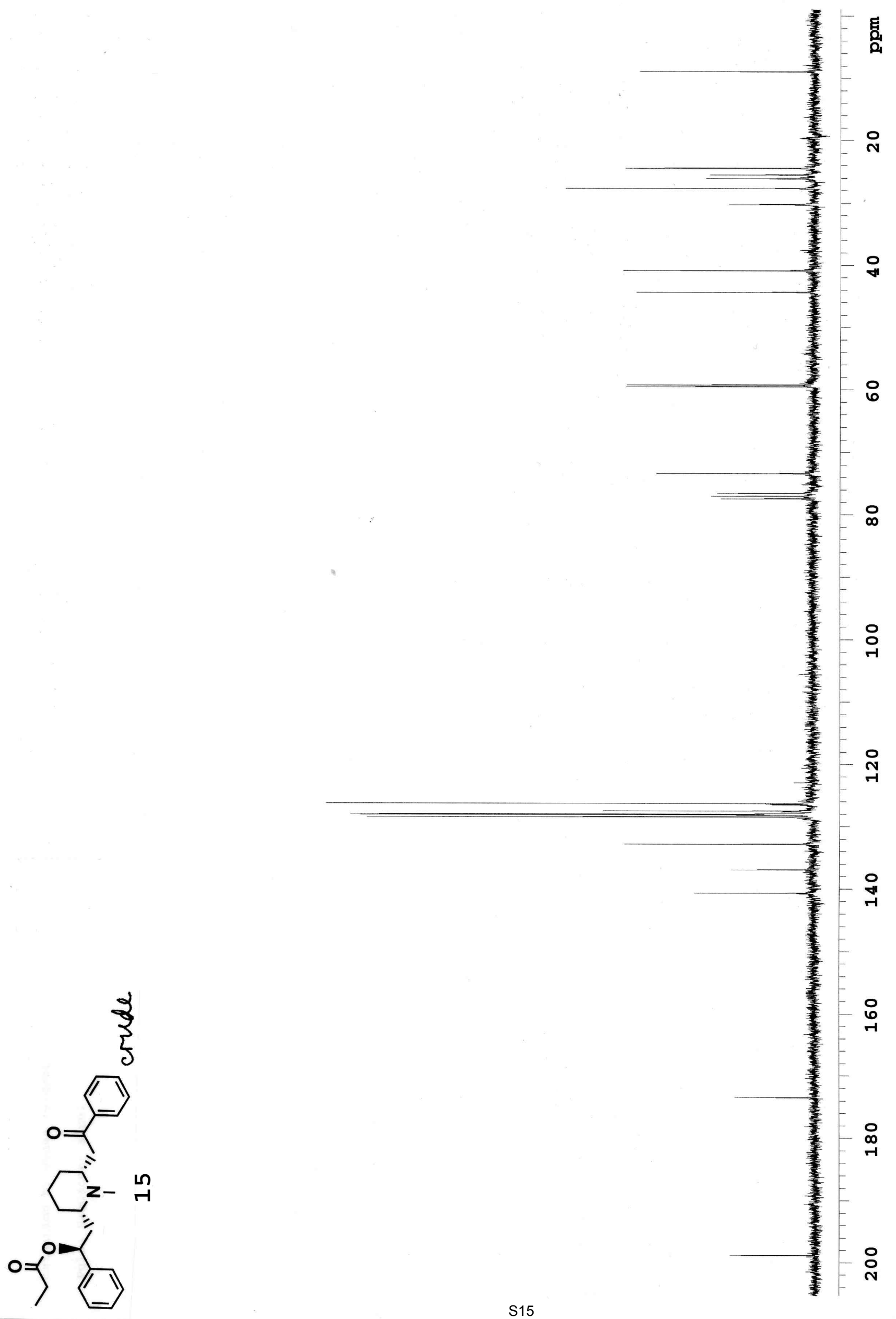

